American Journal of Animal and Veterinary Sciences 2 (4): 104-107, 2007

ISSN 1557-4555

(C) 2007 Science Publications

\title{
Effect of Fig (Ficus carica) Leaf Extract on the Secretion and Content of Cholesterol in Hepg2 Cell
}

\author{
${ }^{1}$ Ahmad Fatemi, ${ }^{1}$ Ali Rasouli and ${ }^{2}$ Farzad Asadi \\ ${ }^{1}$ Department of Pharmacology, University of Tehran, Tehran, Iran \\ ${ }^{2}$ Department of Biochemistry, School of Veterinary Medicine, University of Tehran, Tehran, Iran
}

\begin{abstract}
Traditional medicines remain a source of potential for discovering of new compounds with valuable pharmacological activities. Leaves of Ficus carica were dried, powdered and extracted using methanol (ME).An aliquot of ME was dried and re-extracted by water:chloroform and the other aliquot by water: peteruleum ether. Effect of aqueous fractions of the former (ACR; 0.08, 0.1 and 0.13 $\mathrm{mg} \mathrm{dL}^{-1}$ ), the latter (APR; 0.07, 0.1 and $\left.0.15 \mathrm{mg} \mathrm{dL}^{-1}\right)$ and ME $\left(0.03,0.05\right.$ and $0.08 \mathrm{mg} \mathrm{dL}^{-1}$ ) of Ficus carica leaf on the secretion and cell content of cholesterol in HepG2 cells were studied. Extracts were added to the media in both basal and glucose stimulated conditions and incubated for $48 \mathrm{~h}$. While glucose significantly increased cholesterol secretion $\left(17 \pm 0.76 \mathrm{mg} \mathrm{dL}^{-1}\right) v s$ basal condition $(6.91 \pm 0.66$ $\left.\mathrm{mg} \mathrm{dL}^{-1}\right)$, co-incubation with extracts reduced secretion of cholesterol in many concentrations of the stimulated condition. On the other hand, cholesterol content of HepG2 in glucose stimulated condition $\left(2.73 \pm 0.39 \mathrm{mg} \mathrm{dL}^{-1}\right)$ showed significant increase compared to the basal status $\left(1.96 \pm 0.14 \mathrm{mg} \mathrm{dL}^{-1}\right)$ $(\mathrm{p}<0.001)$.Moreover such decrease was shown in response to many concentrations of the extracts. These properties making the hydro-extracts of fig leaf a potentially safe intervention to modulate postprandial hyperlipidemia.
\end{abstract}

Key words: Ficus carica, leaf extract, cholesterol

\section{INTRODUCTION}

Hypercholesterolemia is one of the major risk factors in development of coronary artery disease in recent years ${ }^{[2,6]}$. Nowadays; many non-prescribed treatments have been available for lowering the cholesterol. In this regard, traditional medicines are pursued as alternative drugs for treatment of hypercholesterolemia. So far, many traditional medicines have been investigated for their therapeutic effects both in humans and in experimental animals $^{[2,12,13,20,21]}$. The hypocholestrolemic effect of citrus peel extract ${ }^{[2]}$, stems of Salvadora persica ${ }^{[8]}$, aqueous extract of Retama raetem ${ }^{[12]}$, aqueous extract of Triticum repens ${ }^{[13]}$ and Anka (a fermented rice product of monascus sp. $)^{[20]}$ have been shown in Rats. The hypocholesterolemic effect of Allium sativum, in human has proved for many years ago ${ }^{[6]}$. In addition, several therapeutic effects have been shown for different parts of Ficus carica, such as hypoglycemia ${ }^{[18]}$, cancer suppressive ${ }^{[16]}$, anthelmintic ${ }^{[5]}$, hypotriglyceridemia $^{[1,14]}$ hypocholestrolemia ${ }^{[15]}$ and bovine papilomatosis ${ }^{[10]}$.
Canal et $a l^{[4]}$ showed that chloroform extract obtained from a decoction of Ficus carica leaves improved the blood cholesterol status in streptozotocin induced diabetic rats ${ }^{[4]}$. Furthermore, Shukla et al., ${ }^{[19]}$ showed that bark aqueous extract of Ficus bengalensis decreased serum low density lipoprotein cholesterol levels (LDL-C) $(59 \%)$ and very low density lipoprotein cholesterol levels $(60 \%)$ in hypercholesterolemic rabbits ${ }^{[19]}$. Thus, the aim of the present study was to extend the findings on the effects of Ficus carica leaf extract on the cholesterol status as secretion and content in both cell line and animal models and also to find its effective constituent.

\section{MATERIALS AND METHODS}

The leaves of Ficus carica were collected from fig trees of Aminabad Institute, School of Veterinary Medicine, University of Tehran in July 2005 at four different times. All leaves were dried by air-flow in shadow, grinded and kept in a glass container. After then, five different extracts were prepared as follows: methanolic extract (ME) was prepared by using

Corresponding Author: Farzad Asadi, Department of Biochemistry, School of Veterinary Medicine, University of Tehran, Tehran, Iran Tel: +982161117130 
suxhelet apparatus model HP-6-500 and concentrated by rotary evaporator model Heidolph. The recent extract was re-extracted by choloroform (CRE) and peterullum ether (PRE), respectively. Again, each recent extract was re-extracted by distilled water and named as ACR and APR for choloroform and peterullum ether, respectively. All extracts were lyophilized by a lyophilizer ( Epsilon-1-12D Chirst Company), rolled in aluminium foil and kept in $-70^{\circ} \mathrm{C}$ until treatments.

Phytochemical analysis for alkaloid, saponin, tannin, flavonoid and glycoside was done ${ }^{[17]}$. HepG2 cells were prepared from Pasture Institute (Tehran, Iran) and cultured in T75 flasks containing DMEM+ $10 \% \mathrm{FBS}+1 \%$ L-glutamine. Incubation was done with increasing concentration of $\mathrm{ME}$ (0.03, 0.05, $\left.0.08 \mathrm{mg} \mathrm{dL}^{-1}\right), \operatorname{CRE}\left(0.08,0.01,0.13 \mathrm{mg} \mathrm{dL}^{-1}\right)$ and ACR $\left(0.07,0.1,0.15 \mathrm{mg} \mathrm{dL}^{-1}\right)$. Experiments were done both in basal and glucose stimulated conditions. Incubations were done for 48 hours at $5 \% \mathrm{CO}^{2}$ in a humid incubator. Then the cells and media were collected and their lipids content were extracted by Bligh and Dyer ${ }^{[3]}$ method . Cholesterol levels were measured in the cell extract by the method of Fossati and Prencipe[1982]. Data were analyzed by 1-way ANOVA, for determination of difference between mean values using Sigma Stat Software. Alfa in all cases was $5 \%(\mathrm{p}<0.05)$.

\section{RESULTS}

Phytochemical analysis shows fig leaf extract (FTE) has minor, moderately and huge amounts of alkaloid, flavonoid and tannin, respectively. Effect of different levels of FTE on the secretion of cholesterol in HepG 2 cells were shown in Table 1.

We showed $\mathrm{ME}\left(0.03,0.05,0.08 \mathrm{mg} \mathrm{dL}^{-1}\right)$, ACR $\left(0.08,0.13 \mathrm{mg} \mathrm{dL}^{-1}\right)$ and $\operatorname{CRE}\left(0.07,0.15 \mathrm{mg} \mathrm{dL}^{-1}\right)$ increased cholesterol secretion higher than the basal levels $(\mathrm{p}<0.001)$.

Furthermore, effect of different levels of FTE on the secretion of cholesterol in stimulated condition was shown in Table 2. It can be seen that ME, APR and ACR can significantly decrease $(\mathrm{p}<0.001)$ secretion of stimulated cholesterol secretion to the basal levels.

Effect of different levels of FTE on the content of cholesterol in basal condition was shown in Table 2. We showed significant increase in the cholesterol content of the cell in response to $\mathrm{ME}\left(0.03 \mathrm{mg} \mathrm{dL}^{-1}\right)$ $(\mathrm{p}<0.001)$ and $\operatorname{ACR}\left(0.07 \mathrm{mg} \mathrm{dL}^{-1}\right)(\mathrm{p}=0.001)$. However, CRE decreased cholesterol values to below the basal levels $\left(0.15 \mathrm{mg} \mathrm{dL}^{-1}\right)$. On the other hand, CRE had no effect on the cellular cholesterol levels, when compared to the stimulated levels.
Table 1: Effect of different extracts of FTE on the secretion of cholesterol in both basal and stimulated conditions in HepG2 cells. Values were expressed as mean $\pm \operatorname{SD}(n=6)$. Different concentrations of each extract were compared with control by 1-way ANOVA

\begin{tabular}{|c|c|c|c|}
\hline Group & Status & $\begin{array}{l}\text { TG concentration } \\
\text { in basal } \\
\text { condition } \\
(\mu \mathrm{g} / \text { well })\end{array}$ & $\begin{array}{l}\text { TG concentration } \\
\text { in stimulated } \\
\text { condition } \\
(\mu \mathrm{g} / \text { well })\end{array}$ \\
\hline$\overline{\mathrm{I}}$ & Control & $6.91 \pm 0.66$ & $17 \pm 0.76$ \\
\hline II & ME $0.03(\%)$ & $9.27 \pm 0.98$ & $10.91 \pm 1.09$ \\
\hline III & ME $0.05(\%)$ & $10.36 \pm 0.65$ & $7.64 \pm 0.53$ \\
\hline IV & ME $0.08(\%)$ & $7.64 \pm 0.49$ & $6.55 \pm 0.6$ \\
\hline $\mathrm{V}$ & PRE $0.08(\%)$ & $8.73 \pm 0.37$ & $6 \pm 0.54$ \\
\hline VI & PRE $0.1(\%)$ & $6.55 \pm 0.76$ & $6.82 \pm 0.14$ \\
\hline VII & PRE $0.13(\%)$ & $7.64 \pm 0.7$ & $8.18 \pm 0.71$ \\
\hline VIII & CRE $0.07(\%)$ & $6 \pm 0.42$ & $10.09 \pm 0.6$ \\
\hline IX & CRE $0.1(\%)$ & $6.55 \pm 0.76$ & $7.36 \pm 0.63$ \\
\hline $\mathrm{X}$ & CRE $0.15(\%)$ & $8.73 \pm 0.65$ & $6 \pm 1.14$ \\
\hline \multirow{3}{*}{\multicolumn{2}{|c|}{$\begin{array}{l}\mathrm{p} \text { values (differences among } \\
\text { different concentrations } \\
\text { of each extract) }\end{array}$}} & I,II; I, III; I, V, & I, II; I,V; I, VII, \\
\hline & & I,VIII;I,X $(<0.001)$, & I, VIII(0.001), \\
\hline & & I,IV; I, VII(0.013) & I, III(0.037), \\
\hline
\end{tabular}

Table 2: Effect of different extracts of FTE on thecontent of cholesterol in both basal and stimulated conditions in HepG2 cells. Values were expressed as mean \pm SD $(n=6)$. Different concentrations of each extract were compared with control by 1-way ANOVA

\begin{tabular}{llll}
\hline Group & Status & $\begin{array}{l}\text { TG concentration } \\
\text { in basal } \\
\text { condition } \\
(\mu \mathrm{g} / \text { well })\end{array}$ & $\begin{array}{l}\text { TG concentration } \\
\text { in stimulated } \\
\text { condition } \\
(\mu \mathrm{g} / \text { well })\end{array}$ \\
\hline I & Control & $1.96 \pm 0.14$ & $2.73 \pm 0.37$ \\
II & ME 0.03(\%) & $2.36 \pm 0.25$ & $2.55 \pm 0.67$ \\
III & ME 0.05(\%) & $1.86 \pm 0.36$ & $1.64 \pm 0.42$ \\
IV & ME 0.08(\%) & $1.73 \pm 0.21$ & $2.18 \pm 0.4$ \\
V & PRE 0.08(\%) & $1.64 \pm 0.95$ & $2.73 \pm 0.44$ \\
VI & PRE 0.1(\%) & $2.18 \pm 0.27$ & $1.45 \pm 0.18$ \\
VII & PRE 0.13(\%) & $2.36 \pm 0.29$ & $1.64 \pm 0.14$ \\
VIII & CRE 0.07(\%) & $2.55 \pm 0.49$ & $2.91 \pm 0.35$ \\
IX & CRE 0.1(\%) & $2 \pm 0.6$ & $1.64 \pm 0.23$ \\
X & CRE $0.15(\%)$ & $1.45 \pm 0.45$ & $1.45 \pm 0.39$ \\
p values (differences among & I,II; I,VIII $(<0.001) ;$ & I,II; I,V; I,VI; I, \\
different concentrations & I,X $(0.007)$ & VIII; I,X $(<0.001) ;$ \\
of each extract) & & I, VII $(0.009) ;$ \\
& & & IX $(0.022)$ \\
\hline
\end{tabular}

Effect of different levels of FTE extracts on the content of cholesterol in the stimulated condition was shown in Table 2. It can be seen that ME (0.05 and0.08 $\left.\mathrm{mg} \mathrm{dL}^{-1}\right)$ and ACR $\left(0.1,0.15 \mathrm{mg} \mathrm{dL}^{-1}\right)$ reduced back the cellular cholesterol content to the basal levels.

\section{DISCUSSION}

In the most of experiments that have been done by different investigators on animal models, the levels of serum cholesterol have been increased in hypercholestrolemic or hyperlipidemic conditions $^{[8,14,15,19]}$ some studies on streptozotocin or 
alloxan induced diabetic rats showed an increase in the levels of serum lipids, LDL-C and VLDL-C parameters ${ }^{[4,12,13]}$. On the other hand, some traditional medicines have effective components against to hyperlipidemic conditions. For example, aqueous extract of Ratama reatem decreased the levels of serum cholesterol in the streptozotocin induced diabetic rats ${ }^{[12]}$.Yang et al., ${ }^{[21]}$ showed that Paenoflorin which was isolated from the methanolic extract of Paeonia lactifora lowered serum cholesterol, LDL-C and trigelycerid levels in an experimentally induced hyperlipidaemic rats ${ }^{[21]}$. These investigations showed that some effective components in plants can decrease the lipid parameters in both hyperlipidemic and diabetic animals.

We showed that all aqueous extracts can significantly decrease $(\mathrm{p}<0.001)$ secretion of cholesterol from the liver cell in both stimulated and basal condition which is resemble to the diabetic animals. These findings are in good agreement with other findings $^{[4,12,13]}$. However, Future studies will need to examine the mechanism of different FTE effects on the basal and glucose induced lipid changes to deduce if the effect is due to altered de novo cholesterol synthesis or increased catabolism of cholesterol.

Our phytochemical experiments showed that leaf of Ficus carica has huge amount of flavonoids. Lee et al., ${ }^{[1]}$ argued that naringenin 7-O-cetyl-synthetic drivate of naringenin is a flavonoid that can inhibit HMG-CoA reductase and ACAT activities in high cholesterol-fed rats ${ }^{[1]}$. Furthermore, it has been shown that tangerine peel extract and mixture of two citrus flavonoids (naringenin and hespridin) significantly lowered the levels of cholesterol in both plasma and liver. Hence, it can be deduced that inhibition of HMGCoA reductase and ACAT activities may be contributed to the flavonoids in the fig leaf extract.

In conclusion these preliminary data suggest that hydroextract of fig leaf administration may be an alternative method to reduce hyperlipidemia, particularly postprandially induced ones.

\section{REFERENCES}

1. Asadi, F., M. Pourkabir, R. Maclaren and A. Shahriari, 2006. Alterations to lipid parameters in response to fig tree (Ficus carica) leaf extract in chicken liver slices. Turk. J. Vet. Anim. Sci. 30: 315-318.

2. Bok, S.H., S.H. Lee, Y.B. Park, K.H. Bae, K.H. Son, T.S. Jeong and M.S. Choi, 1999. Plasma and hepatic cholesterol and hepatic activities of HMG- CoA Reductase and ACAT are lower in rat citrus peel extract of a mixture of citrus biflavonoids. J. Nutr.129: 1182-5.
3. Bligh, E.G. and W.J. Dyer, 1959. A rapid method for total lipid extraction and purification.Can. J. Biochem. Physiol.37: 911-917.

4. Canal, J.R., M.D. Torres, A. Romero and C. Perez, 2002. A chloroform extract obtained from a decoction of Ficus carica leaves, improve the chlosterolaemia of rats with streptozocin-induced diabetes. Acta Physiol. Hung. 87: 71-76.

5. De-Amorin, A.H., H.R. Borba, L.D. Carauta and M.A. Kaplan, 1999. Anthelmintic activity of the latex of Ficus carica. J Ethnopharmacol. 64: 255258.

6. Evans W. Charles, 2002. Trease and evana pharmacognosy. 15th Edn. Saunders Company.

7. Fossati, P., L. Prencipe, 1982. Determination of cholesterol . Clin. Chem. 28: 2077.

8. Galati E. M., M.T. Monforte, A.M. Forestieri, N. Micell, A. Bader and A. Trorato, 1999. Salvadora persica L :Hypolipidemic activity on experimental hypercholesterolemic in rat. Phytomedicine. 6: 181-5.

9. Goldstein J.L., M.S. Brown, 1983. Lipid extraction from cultured HepG2 cells. Methods Enzymol. 98: 241-261.

10. Hemmatzadeh F., A. Fatemi, F. Amini, 2003. Therapeutic effect of fig tree latex on bovine papilomatosis. J. Vet. Med. B Infect. Dis. Vet. Public Health 50: 473-76.

11. Lee M.K., S.S. Moon, S.E. Lee, S.H. Bok, TS. Jeong, YB. Park, MS Choi, 2003. Naringenin,7-O-cetyl ether as inhibitor of HMGCoA reductase and modulator of plasma and hepatic lipids in high cholesterol-feed rats. 11: 393-398.

12. Maghrani M., A. Lemhardri, N.A. Zeggwagh, A. EI- Amraoui, M. Haloui, H. Jud, M. Eddouks, 2004a. Effect of Retama raetam on lipid metabolism in normal and recent diabetic rats. J. Ethnopharmacol. 90: 323-9.

13. Maghrani, M., A. Lemhardri, NA. Zeggwagh, A. EI-Amraoui, M. Haloui, H. Jud, M. Eddouks, 2004b. Effect of Triticum repens on lipid metabolism in normal and recent diabetic rats. J. Ethnopharmacol. 90: 331-7.

14. Perez C., J.R. Canal, J. E. Campillo, A. Romero and M.D. Torres, 1999a. Hypotriglyceridemic activity of Ficus carica leaves in experimental Hypertriglyceridemic rats. Phyto. Res. B 188-191.

15 Perez C., JR. Canal, A. Romero and M.D. Torres, 1999b. Experimental hypertriglyceridemia and hypercholesterolaemia in rats. Acta Physiol. Hung.86: 57-68. 
16. Rubnov, S.Y., R. Kashman, M. Rabinowitz, M. Schlesinger and R. Mcchoulam, 2000. Suppressor of cancer cell proliferation from fig (Ficus carica) resin isolation and structure elucidation. J. Nut. Prod. 64: 993-6.

17. Samsam Shariat, 1989. Analysis and recognition of planta media microscopic and chromatographical methods. Mashal publication. isfahan. 1 (31): 101-164.

18. Serraclara, A.F., C. Hawkins, C. Perez, E. Dominguez, J.E. Campillo, M.D. Torres, 1998. Hypoglycemic action of an oral fig-leaf decoction in type-1 diabetic patients Diabet. Res. Clin. Prac.39:19-22.
19. Shuka R., S. Gupta, J.K. Gambhir, K.M. Prabhu and P.S. Murthy, 2004. Antioxidant effect of aqueous extract of the bark of Ficus bengaliens in hypercholesterolaemic rabbits. J Ethnopharmacol. 92: 47-51.

20. Wang I.K., S.Y. Lin- Shiao, P.C. Chen and J.K. Lin, 2000. Hypotriglyceridemic Effect of Anka (a fermented rice prouduct of monascus sp.) in rats. J. Agric. Food. Chem. 48: 3188-3189.

21. Yang H., W.K. Ko, JY. Kim and HS. Ro, 2004. Paeoniflorin: an anti-hyperlipidemic agent from Paeonia lactifora.Fitoterapia. 2004.751: 45-9. 